Buletin Ilmiah Math. Stat. dan Terapannya (Bimaster)

Volume 08, No. 2 (2019), hal 281 - 288.

\title{
PENENTUAN PREMI ASURANSI JIWA BERJANGKA UNTUK KASUS TIGA ORANG TERTANGGUNG MENGGUNAKAN ANUITAS REVERSIONARY
}

\author{
Arif Fiqri Syawaludin, Neva Satyahadewi, Hendra Perdana
}

\begin{abstract}
INTISARI
Anuitas reversionary adalah nilai anuitas pada peserta asuransi jiwa dalam menentukan premi yang harus dibayarkan peserta asuransi ketika salah satu peserta asuransi meninggal dunia selama masa kontrak yang telah ditetapkan. Asuransi jiwa joint life merupakan jenis asuransi jiwa yang melindungi dua jiwa atau lebih. Perhitungan premi dapat ditentukan dengan mengkombinasikan status joint life pada peserta asuransi. Peserta pada penelitian ini dibatasi hanya tiga orang tertanggung yaitu orang tua dan anaknya. Pembayaran premi dan pemberian santunan dimulai ketika salah satu dari tertanggung meninggal dunia selama jangka waktu kontrak asuransi. Pembayaran premi akan berlanjut kepada tertanggung lainnya yang masih bertahan hidup sampai dengan sisa jangka waktu kontrak asuransi. Pada penelitian ini premi yang harus dibayarkan untuk suami dan istri berbeda. Biaya premi asuransi jiwa dipengaruhi oleh jenis kelamin, usia, besarnya santunan, dan tingkat suku bunga.
\end{abstract}

Kata kunci: Asuransi Joint Life, Anuitas Reversionary, Premi, Santunan.

\section{PENDAHULUAN}

Pada dasarnya setiap manusia memerlukan perlindungan dari suatu kejadian yang tidak dapat diprediksi dikemudian hari. Perlindungan ini dapat berupa perlindungan jiwa maupun harta benda. Asuransi adalah jasa yang diberikan suatu perusahaan untuk memberikan perlindungan atas suatu kejadian yang tak terduga dan diharapkan. Asuransi merupakan perjanjian antara dua pihak atau lebih dengan membayarkan suatu premi dalam jangka waktu tertentu yang menjamin perlindungan dengan memberikan santunan kepada pesertanya. Asuransi pada umumnya dibagi dalam dua kelompok utama, yaitu asuransi jiwa dan asuransi kerugian. Asuransi jiwa berkaitan dengan diri manusia, sedangkan asuransi kerugian berkaitan dengan harta milik beserta kepentingan dan tanggung jawab hukumnya.

Asuransi jiwa yang berkembang di Indonesia ada dua macam, yaitu asuransi jiwa tunggal (individual insurance) dan asuransi jiwa bersama (group insurance). Pada asuransi jiwa tunggal, penanggung (perusahaan asuransi) memberikan perlindungan untuk satu orang (tunggal), sedangkan jumlah tertanggung pada asuransi jiwa bersama lebih dari satu orang. Salah satu produk asuransi jiwa bersama adalah asuransi joint life. Asuransi joint life merupakan asuransi yang menanggung dua jiwa atau lebih dimana manfaatnya dibayarkan jika salah seorang tertanggung meninggal dunia [1]. Asuransi joint life juga bisa dikombinasikan dengan anuitas reversionary. Hal ini artinya jika salah seorang dari peserta tersebut meninggal dunia maka peserta yang lain akan mendapatkan santunan dan melanjutkan pembayaran premi hingga akhir kontrak asuransi dengan status joint life.

Penelitian ini bertujuan menganalisis perhitungan premi tahunan untuk pemegang asuransi joint life dengan anuitas reversionary dalam kasus tiga orang tertanggung, yaitu kedua orang tua dan anaknya. Penentuan salah satu peserta dari tiga orang tertanggung yang meninggal dunia dibatasi hanya untuk kedua orang tua. Perhitungan premi tahunan dimulai dengan mengumpulkan informasi mengenai jangka waktu asuransi tersisa, santunan, tingkat suku bunga, dan usia kedua orang tua dan anaknya. Langkah selanjutnya menghitung anuitas awal dan akhir dari kedua orang tua dan anaknya. Dalam masa asuransi apabila suami mengalami suatu hal yang mengakibatkan kehilangan hidupnya, maka akan dicari nilai anuitas akhir untuk istri dan anak. Jika istri dalam masa asuransi mengalami suatu hal yang mengakibatkan kehilangan hidupnya, maka akan dicari nilai anuitas akhir untuk suami dan anak. Langkah terakhir yaitu mendapatkan nilai premi yang harus dibayarkan dengan anuitas reversionary. 


\section{PELUANG HIDUP TUNGGAL}

Peluang usia seseorang meninggal menjadi salah satu faktor yang mempengaruhi asuransi jiwa. Perhitungan yang menggunakan hubungan antara usia dan waktu disebut life function (Fungsi Kehidupan). Life function ini bisa digunakan untuk menentukan nilai peluang hidup dan nilai peluang meninggal. Berikut ini adalah rumus-rumus yang berhubungan dengan nilai peluang hidup dan nilai peluang meninggal, yaitu [2]:

1. Nilai kemungkinan $x$ untuk hidup dalam jangka waktu $n$ tahun kedepan, dinotasikan dengan:

$$
{ }_{n} p_{x}=\frac{l_{x+1}}{l_{x}}
$$

2. Nilai kemungkinan $x$ untuk meninggal dalam jangka waktu $n$ tahun kedepan, dinotasikan dengan:

$$
{ }_{n} q_{x}=1-{ }_{n} p_{x}=1-\frac{l_{x+1}}{l_{x}}
$$

keterangan:

$l_{x+1}=$ jumlah orang yang hidup diusia $(x+1)$ tahun.

$l_{x}=$ jumlah orang yang hidup diusia $x$ tahun.

\section{PELUANG HIDUP JOINT LIFE}

Terdapat dua orang peserta asuransi jiwa bersama joint life berusia $x$ dan $y$ tahun dengan asumsi $(x)$ dan $(y)$ akan tetap hidup selama $n$ tahun adalah saling bebas, maka peluang hidup gabungannya, yaitu [1]:

$$
{ }_{n} p_{x y}=\left({ }_{n} p_{x}\right)\left({ }_{n} p_{y}\right)
$$

Peluang salah satu dari dua orang yang berusia $x$ dan $y$ tahun akan meninggal dalam kurun waktu $n$ tahun, yaitu:

$$
\begin{aligned}
{ }_{n} q_{x y} & =1-{ }_{n} p_{x y} \\
& =1-\left({ }_{n} p_{x}\right)\left({ }_{n} p_{y}\right)
\end{aligned}
$$

\section{TINGKAT SUKU BUNGA}

Pada saat pemilik polis membayar premi kepada perusahaan asuransi, dana yang ada di perusahaan tidak diam, tetapi bersama dana pemilik polis lainnya dan ditanamkan untuk mendapatkan bunga. Pendapatan investasi pada premi merupakan pertimbangan kedua dalam perhitungan tarif premi [3]. Tingkat suku bunga dalam asuransi didefinisikan sebagai fungsi diskonto, yaitu [2]:

$$
v^{t}=\frac{1}{(i+1)^{t}}
$$

keterangan:

$i \quad$ = tingkat suku bunga

$t=$ tahun

$v^{t}=$ fungsi diskonto untuk tahun ke- $t$

\section{ANUITAS HIDUP PADA ASURANSI TUNGGAL}

Anuitas merupakan suatu rangkaian pembayaran yang secara berkelanjutan dilakukan setiap selang waktu tertentu dengan besar uang yang sama [4]. Pembayaran dapat dilakukan mingguan, bulanan, tahunan, dan jangka waktu lainnya yang berkala. Nilai anuitas hidup pada asuransi tunggal dapat dirumuskan sebagai berikut [1]:

1. Nilai anuitas hidup awal berjangka $n$ tahun untuk seseorang berusia $x$ tahun: 


$$
\ddot{a}_{x: n}=\sum_{t=0}^{n-1} v^{t}{ }_{t} p_{x}
$$

2. Nilai anuitas hidup akhir berjangka $n$ tahun untuk seseorang berusia $x$ tahun:

$$
a_{x: n}=\sum_{t=1}^{n} v^{t}{ }_{t} p_{x}
$$

\section{ANUITAS HIDUP PADA ASURANSI JOINT LIFE}

Anuitas joint life adalah suatu rangkaian pembayaran oleh dua tertanggung atau lebih, dimana pembayaran berhenti apabila salah satu tertanggung meninggal dunia. Nilai anuitas hidup pada asuransi joint life dapat dirumuskan sebagai berikut [1]:

1. Nilai anuitas hidup awal joint life berjangka $n$ tahun untuk seseorang berusia $x$ tahun:

$$
\ddot{a}_{x y: n}=\sum_{t=0}^{n-1} v^{t}{ }_{t} p_{x y}=\sum_{t=0}^{n-1} v^{t}\left({ }_{t} p_{x}\right)\left({ }_{t} p_{y}\right)
$$

2. Nilai anuitas hidup akhir joint life berjangka $n$ tahun untuk seseorang berusia $x$ tahun:

$$
a_{x y: n}=\sum_{t=1}^{n} v^{t}{ }_{t} p_{x y}=\sum_{t=1}^{n} v^{t}\left({ }_{t} p_{x}\right)\left({ }_{t} p_{y}\right)
$$

\section{ANUITAS REVERSIONARY PADA DUA PESERTA}

Anuitas reversionary merupakan suatu serangkaian pembayaran yang dimulai pada tahun kematian suami $(x)$, dimana istri $(y)$ masih akan hidup sampai akhir kontrak asuransi yang telah ditetapkan. Nilai sekarang dari anuitas reversionary, yaitu[1]:

$$
\begin{aligned}
a_{x \mid y: n} & =a_{y: n}-a_{x y: n} \\
& =\sum_{t=1}^{n} v^{t}{ }_{t} p_{y}-\sum_{t=1}^{n} v^{t}{ }_{t} p_{x y} \\
& =\sum_{t=1}^{n} v^{t}{ }_{t} p_{y}-\sum_{t=1}^{n} v^{t}\left({ }_{t} p_{x}\right)\left({ }_{t} p_{y}\right)
\end{aligned}
$$

\section{ANUITAS REVERSIONARY PADA TIGA PESERTA}

Misalkan sebuah asuransi jiwa joint life mempunyai tertanggung yang terdiri dari suami $(x)$, istri $(y)$, dan anak $(z)$, dimana suami $(x)$ merupakan orang yang berusia $x$ tahun, istri $(y)$ merupakan orang yang berusia $y$ tahun, dan anak $(z)$ merupakan orang yang berusia $z$ tahun. Berikut ini akan diuraikan nilai anuitas reversionary pada asuransi jiwa joint life, yaitu [1]:

1. Jika istri $(y)$ dan anak $(z)$ hidup bersamaan dengan status joint life dimulai pada akhir tahun pada waktu suami $(x)$ meninggal, yang masih hidup adalah istri $(y)$ dan anak $(z)$ sampai pada akhir tahun polis ke- $n$. Nilai anuitas untuk istri $(y)$ dan anak $(z)$, jika pembayaran anuitas setiap akhir periode selama $n$ tahun dengan tingkat suku bunga $(i)$, yaitu:

$$
\begin{aligned}
a_{x \mid y z: n}= & a_{y z: n}-a_{x y z: n} \\
= & \sum_{t=1}^{n} v^{t}{ }_{t} p_{y z}-\sum_{t=1}^{n} v^{t}{ }_{t} p_{x y z} \\
& =\left[\sum_{t=1}^{n} v^{t}\left({ }_{t} p_{y}\right)\left({ }_{t} p_{z}\right)\right]-\left[\sum_{t=1}^{n} v^{t}\left({ }_{t} p_{x}\right)\left({ }_{t} p_{y}\right)\left({ }_{t} p_{z}\right)\right]
\end{aligned}
$$

2. Jika suami $(x)$ dan anak ( $z$ ) hidup bersamaan dengan status joint life dimulai pada akhir tahun pada waktu istri $(y)$ meninggal, yang masih hidup adalah suami $(x)$ dan anak $(z)$ sampai pada akhir 
tahun polis ke- $n$. Nilai anuitas untuk suami $(x)$ dan anak $(z)$, jika pembayaran anuitas setiap akhir periode selama $n$ tahun dengan tingkat suku bunga $(i)$, yaitu:

$$
\begin{aligned}
a_{y \mid x z: n} & =a_{x z: n}-a_{x y z: n} \\
& =\sum_{t=1}^{n} v^{t}{ }_{t} p_{x z}-\sum_{t=1}^{n} v^{t}{ }_{t} p_{x y z} \\
& =\left[\sum_{t=1}^{n} v^{t}\left({ }_{t} p_{x}\right)\left({ }_{t} p_{z}\right)\right]-\left[\sum_{t=1}^{n} v^{t}\left({ }_{t} p_{x}\right)\left({ }_{t} p_{y}\right)\left({ }_{t} p_{z}\right)\right]
\end{aligned}
$$

\section{PREMI TAHUNAN DENGAN ANUITAS REVERSIONARY}

Premi tahunan adalah premi yang dibayarkan pada setiap awal permulaan tahun oleh peserta asuransi. Pada anuitas reversionary, premi tahunan mulai dibayar setelah salah satu orang dari peserta asuransi jiwa bersama meninggal dunia sampai akhir tahun ke- $n$. Berikut ini akan diuraikan premi berjangka pada asuransi jiwa bersama joint life, yaitu [1]:

1. Jika suami $(x)$ dan istri $(y)$ hidup bersamaan, maka:

a. Nilai anuitas reversionary untuk istri $(y)$ setelah suami $(x)$ meninggal dunia. Pembayaran premi tahunan dengan jangka waktu $n$ tahun dengan santunan sebesar $R$, yaitu:

$$
P\left(a_{x \mid y: n}\right)=R \frac{a_{x \mid y: n}}{\ddot{a}_{x y: n}}
$$

b. Nilai anuitas reversionary untuk suami $(x)$ setelah istri $(y)$ meninggal dunia. Pembayaran premi tahunan dengan jangka waktu $n$ tahun dengan santunan sebesar $R$, yaitu:

$$
P\left(a_{y \mid x: n}\right)=R \frac{a_{y \mid x: n}}{\ddot{a}_{x y: n}}
$$

2. Jika suami $(x)$, istri $(y)$, dan anak ( $z$ ) hidup bersamaan, maka:

a. Nilai anuitas reversionary untuk istri $(y)$ dan anak $(z)$ setelah suami $(x)$ meninggal dunia. Pembayaran premi tahunan dengan jangka waktu $n$ tahun dengan santunan sebesar $R$, yaitu:

$$
P\left(a_{x \mid y z: n}\right)=R \frac{a_{x \mid y z: n}}{\ddot{a}_{x y z: n}}
$$

b. Nilai anuitas reversionary untuk suami $(x)$ dan anak $(z)$ setelah istri $(y)$ meninggal dunia. Pembayaran premi tahunan dengan jangka waktu $n$ tahun dengan santunan sebesar $R$, yaitu:

$$
P\left(a_{y \mid x z: n}\right)=R \frac{a_{y \mid x z: n}}{\ddot{a}_{x y z: n}}
$$

\section{STUDI KASUS}

Pada penelitian ini akan diberikan studi kasus sebagai simulasi penentuan premi asuransi jiwa berjangka untuk kasus tiga orang tertanggung yaitu kedua orang tua dan anaknya menggunakan anuitas reversionary. Penentuan salah satu peserta dari tiga orang tertanggung yang meninggal dunia dibatasi hanya untuk kedua orang tua. Proses penyelesaian perhitungan premi menggunakan bantuan software Microsoft Excel. Perhitungan premi tahunan dengan menggunakan anuitas reversionary akan diterapkan dalam contoh kasus sebagai berikut:

1. Contoh Kasus Suami Meninggal Dunia

Sebuah perusahaan asuransi menawarkan produk asuransi kepada sebuah keluarga. Keluarga tersebut berjumlah 3 orang yang bernama Dandi $(x)$ sebagai kepala keluarga berumur 45 tahun, 
Melati (y) sebagai istri berumur 39 tahun, dan Yaya (z) sebagai anak berumur 16 tahun. Perusahaan tersebut menawarkan sebuah produk dengan jangka waktu 25 tahun dan uang santunan sebesar Rp 100.000.000 untuk tiap individu bila terjadi kematian. Tingkat suku bunga (i) yang digunakan yaitu 6\%. Pada kasus ini diasumsikan Dandi meninggal 10 tahun setelah kontrak asuransi dimulai. Ahli waris akan mendapatkan santunan sebesar Rp100.000.000 saat Dandi meninggal dunia, kemudian pembayaran premi baru akan dimulai.

Berdasarkan kasus pertama didapatkan informasi Dandi meninggal dunia 10 tahun setelah kontrak asuransi dimulai. Usia Dandi 55 tahun, usia Melati 49 tahun, dan anaknya Yaya berusia 26. Jangka waktu asuransi tersisa 15 tahun dengan tingkat suku bunga sebesar $6 \%$ dan santunan sebesar Rp100.000.000. Premi yang harus dibayarkan ketika Dandi meninggal dunia, yaitu:

Nilai anuitas reversionary diperoleh menggunakan Persamaan (11), yaitu:

1. Nilai anuitas awal berjangka dari $x, y$, dan $z$ :

$$
\begin{aligned}
\ddot{a}_{x y z: n} & =\sum_{t=0}^{n-1} v^{t}{ }_{t} p_{x y z} \\
& =9,22992
\end{aligned}
$$

Sehingga didapat nilai anuitas awal berjangka dari Dandi, Melati, dan Yaya adalah sebesar 9,22992

2. Nilai anuitas akhir berjangka dari $x, y$, dan $z$ :

$$
\begin{aligned}
a_{x y z: n} & =\sum_{t=1}^{n} v^{t}{ }_{t} p_{x y z} \\
& =8,51590
\end{aligned}
$$

Sehingga didapat nilai anuitas akhir berjangka dari Dandi, Melati, dan Yaya adalah sebesar 8,51590

3. Nilai anuitas akhir berjangka dari $y$, dan $z$ :

$$
\begin{aligned}
a_{y z: n} & =\sum_{t=1}^{n} v^{t}{ }_{t} p_{y z} \\
& =9,34247
\end{aligned}
$$

Sehingga didapat nilai anuitas akhir berjangka dari Melati, dan Yaya adalah sebesar 9,34247 Berdasarkan ketiga perhitungan diatas dan menggunakan Persamaan (15), maka premi dengan anuitas reversionary diperoleh:

$$
\begin{aligned}
P\left(a_{x \mid y z: n}\right) & =R\left(\frac{a_{y z: n}-a_{x y z: n}}{\ddot{a}_{x y z: n}}\right) \\
& =100.000 .000\left(\frac{9,34247-8,51590}{9,22992}\right) \\
& =8.955 .387
\end{aligned}
$$

Sehingga didapat nilai premi tahunan berjangka yang harus dibayarkan Melati dan Yaya setelah Dandi meninggal dunia adalah sebesar Rp 8.955.387

2. Contoh Kasus Istri Meninggal Dunia

Sebuah perusahaan asuransi menawarkan produk asuransi kepada sebuah keluarga. Keluarga tersebut berjumlah 3 orang yang bernama Dandi (x) sebagai kepala keluarga berumur 45 tahun, Melati (y) sebagai istri berumur 39 tahun, dan Yaya (z) sebagai anak berumur 16 tahun. Perusahaan tersebut menawarkan sebuah produk dengan jangka waktu 25 tahun dan uang santunan sebesar Rp100.000.000 untuk tiap individu bila terjadi kematian. Tingkat suku bunga (i) yang digunakan 
yaitu 6\%. Pada kasus ini diasumsikan Melati meninggal 10 tahun setelah kontrak asuransi dimulai. Ahli waris akan mendapatkan santunan sebesar Rp100.000.000 saat Melati meninggal dunia, kemudian pembayaran premi baru akan dimulai.

Berdasarkan kasus kedua didapatkan informasi Melati meninggal dunia 10 tahun setelah kontrak asuransi dimulai. Usia Dandi 55 tahun, usia Melati 49 tahun, dan anaknya Yaya berusia 26. Jangka waktu asuransi tersisa 15 tahun dengan tingkat suku bunga sebesar 6\% dan santunan sebesar Rp100.000.000. Premi yang harus dibayarkan ketika Melati meninggal dunia, yaitu:

Nilai anuitas reversionary diperoleh menggunakan Persamaan (12), yaitu:

1. Nilai anuitas awal berjangka dari $x, y$, dan $z$ :

$$
\begin{aligned}
\ddot{a}_{x y z: n} & =\sum_{t=0}^{n-1} v^{t}{ }_{t} p_{x y z} \\
& =9,22992
\end{aligned}
$$

Sehingga didapat nilai anuitas awal berjangka dari Dandi, Melati, dan Yaya adalah sebesar 9,22992.

2. Nilai anuitas akhir berjangka dari $x, y$, dan $z$ :

$$
\begin{aligned}
a_{x y z: n} & =\sum_{t=1}^{n} v^{t}{ }_{t} p_{x y z} \\
& =8,51590
\end{aligned}
$$

Sehingga didapat nilai anuitas akhir berjangka dari Dandi, Melati, dan Yaya adalah sebesar 8,51590 .

3. Nilai anuitas awal berjangka dari $x$, dan $z$ :

$$
\begin{aligned}
a_{x z: n} & =\sum_{t=1}^{n} v^{t}{ }_{t} p_{x z} \\
& =8,80059
\end{aligned}
$$

Sehingga didapat nilai anuitas akhir berjangka dari Dandi dan Yaya adalah sebesar 8,80059.

Berdasarkan ketiga perhitungan diatas dan menggunakan Persamaan (16), maka premi dengan anuitas reversionary diperoleh:

$$
\begin{aligned}
P\left(a_{x \mid y z: n}\right) & =R\left(\frac{a_{x z: n}-a_{x y z: n}}{\ddot{a}_{x y z: n}}\right) \\
& =100.000 .000\left(\frac{8,80059-8,51590}{9,22992}\right) \\
& =3.084 .430
\end{aligned}
$$

Sehingga didapat nilai premi tahunan berjangka yang harus dibayarkan Dandi dan Yaya setelah Melati meninggal dunia adalah sebesar Rp3.084.430.

\section{PERBANDINGAN PREMI BERDASARKAN USIA DAN TINGKAT SUKU BUNGA}

Pada Tabel 1 dan Tabel 2 menunjukkan perbandingan pembayaran premi berdasarkan usia dan tingkat suku bunga bervariasi yang ditampilkan sebagai berikut:

Tabel 1 Kasus suami meninggal dunia

\begin{tabular}{cccccc}
\hline $\boldsymbol{x}$ & $\boldsymbol{y}$ & $\boldsymbol{z}$ & $\boldsymbol{i}=\mathbf{4 , 2 5 \%}$ & $\boldsymbol{i}=\mathbf{5 , 2 5 \%}$ & $\boldsymbol{i}=\mathbf{6 , 0 0 \%}$ \\
\hline 55 & 49 & 26 & 9.625 .238 & 9.236 .313 & 8.955 .387 \\
55 & 55 & 26 & 9.446 .158 & 9.064 .296 & 8.788 .585 \\
49 & 55 & 26 & 5.502 .345 & 5.274 .569 & 5.110 .020 \\
\hline
\end{tabular}


Berdasarkan Tabel 1 ditunjukkan premi yang dibayarkan oleh istri dan anak ketika suami meninggal dunia. Jika suami berusia 55 tahun, istri berusia 49 tahun, dan anak berusia 26 tahun (suami lebih tua dari istri), maka premi yang dibayarkan sebesar Rp9.625.238 ( $i=4,25 \%)$, Rp9.236.313 ( $i=5,25 \%)$, dan Rp8.955.387 ( $i=6,00 \%$ ), selanjutnya jika suami berusia 55 tahun, istri berusia 55 tahun, dan anak berusia 26 tahun (suami berumur sama dengan istri), maka premi yang dibayarkan sebesar Rp9.446.158 ( $i=4,25 \%$ ), Rp9.064.296 ( $i=5,25 \%)$, dan Rp8.788.585 ( $i=6,00 \%)$, tetapi ketika suami berusia 49 tahun, istri berusia 55 tahun, dan anak berusia 26 tahun (suami lebih muda dari istri), maka premi yang dibayarkan sebesar Rp5.502.345 ( $i=4,25 \%$ ), Rp5.274.569 ( $i=5,25 \%)$, dan Rp5.110.020 ( $i=6,00 \%)$. Semakin tinggi tingkat suku bunga, maka semakin murah premi yang harus dibayarkan.

Tabel 2 Kasus istri meninggal dunia

\begin{tabular}{cccccc}
\hline $\boldsymbol{x}$ & $\boldsymbol{y}$ & $\boldsymbol{z}$ & $\boldsymbol{i}=\mathbf{4 , 2 5 \%}$ & $\boldsymbol{i}=\mathbf{5 , 2 5 \%}$ & $\boldsymbol{i}=\mathbf{6 , 0 0 \%}$ \\
\hline 55 & 49 & 26 & 3.320 .119 & 3.183 .278 & 3.084 .430 \\
55 & 55 & 26 & 5.758 .911 & 5.528 .607 & 5.362 .289 \\
49 & 55 & 26 & 5.927 .652 & 5.690 .905 & 5.519 .815 \\
\hline
\end{tabular}

Berdasarkan Tabel 2 ditunjukkan premi yang dibayarkan oleh suami dan anak ketika istri meninggal dunia. Jika suami berusia 55 tahun, istri berusia 49 tahun, dan anak berusia 26 tahun (istri lebih muda dari suami), maka premi yang dibayarkan sebesar Rp3.320.119 ( $i=4,25 \%)$, Rp3.183.278 ( $i=5,25 \%)$, dan Rp3.084.430 ( $i=6,00 \%$ ), selanjutnya jika suami berusia 55 tahun, istri berusia 55 tahun, dan anak berusia 26 tahun (istri berumur sama dengan suami), maka premi yang dibayarkan sebesar Rp5.758.911 ( $i=4,25 \%)$, Rp5.528.607 ( $i=5,25 \%$ ), dan Rp5.362.289 ( $i=6,00 \%$ ), tetapi ketika suami berusia 49 tahun, istri berusia 55 tahun, dan anak berusia 26 tahun (istri lebih tua dari suami), maka premi yang dibayarkan sebesar Rp5.927.652 ( $i=4,25 \%)$, Rp5.690.905 ( $i=5,25 \%)$, dan Rp5.519.815 ( $i=6,00 \%)$. Semakin tinggi tingkat suku bunga, maka semakin murah premi yang harus dibayarkan.

Pada Tabel 1 dan Tabel 2 menunjukkan bahwa pembayaran premi lebih mahal ketika suami meninggal dibandingkan istri meninggal. Hal ini dikarenakan peluang kematian suami (laki-laki) berdasarkan Tabel Mortalita Indonesia lebih besar dibandingkan istri (perempuan). Premi yang harus dibayarkan peserta asuransi selain dipengaruhi oleh jenis kelamin juga dipengaruhi oleh usia dan tingkat suku bunga. Semakin bertambahnya usia peserta dalam mengikuti asuransi, maka semakin mahal premi yang dibayarkan. Hal ini dikarenakan peluang kematian seseorang semakin besar dengan bertambahnya usia. Mahalnya pembayaran premi juga dipengaruhi oleh tingkat suku bunga. Ketika tingkat suku bunga semakin tinggi, maka semakin murah premi yang harus dibayarkan. Hal ini dikarenakan tingkat suku bunga merupakan variabel dari fungsi diskonto, sehingga semakin besar tingkat suku bunga, maka semakin kecil nilai dari fungsi diskonto.

\section{PENUTUP}

Asuransi jiwa joint life yang dikombinasikan dengan anuitas reversionary merupakan kontrak asuransi yang dimulai apabila salah satu peserta asuransi meninggal dunia dalam jangka waktu kontrak asuransi dan peserta yang lain mendapatkan santunan. Ketika salah satu peserta tersebut meninggal, ahli waris akan mendapatkan besar santunan kemudian pembayaran premi baru akan dimulai sampai lama jangka waktu perlindungan asuransi selesai. Pada penelitian ini didapatkan pembayaran premi lebih mahal ketika suami meninggal dibandingkan istri meninggal. Hal ini dikarenakan peluang kematian suami (laki-laki) berdasarkan Tabel Mortalita Indonesia lebih besar dibandingkan istri (perempuan). Premi yang harus dibayarkan peserta asuransi selain dipengaruhi oleh jenis kelamin juga dipengaruhi oleh usia dan tingkat suku bunga. Semakin bertambah usia peserta dalam mengikuti asuransi, maka semakin mahal premi yang dibayarkan. Hal ini dikarenakan peluang kematian seseorang semakin besar dengan bertambahnya usia. Ketika tingkat suku bunga semakin tinggi, maka semakin murah premi yang 
harus dibayarkan. Hal ini dikarenakan tingkat suku bunga merupakan variabel dari fungsi diskonto, sehingga semakin tinggi tingkat suku bunga, maka semakin kecil nilai dari fungsi diskonto.

\section{DAFTAR PUSTAKA}

[1]. Bowers NL, Gerber HU, Hickman JC, Jones DA, Nesbitt CJ. Actuarial Mathematics Second Edition. Illinois: Society Of Actuaries; 1997.

[2]. Futami T. Matematika Asuransi Jiwa Bagian I. Tokyo: Incorporated Foundation Oriental Life Insurance Cultural Development Center; 1993.

[3]. Achdijad D. Prinsip-Prinsip Aktuaria pada Asuransi Jiwa. Jakarta: Gunadarma; 1990.

[4]. Frensidy B. Matematika Keuangan. Jakarta: Salemba Empat; 2007.

$\begin{array}{lll}\text { ARIF FIQRI SYAWALUDIN } & : & \begin{array}{l}\text { Jurusan Matematika FMIPA UNTAN, Pontianak } \\ \text { ariffiqrisyawaludin@ gmail.com }\end{array} \\ \text { NEVA SATYAHADEWI } & : & \begin{array}{l}\text { Jurusan Matematika FMIPA UNTAN, Pontianak } \\ \text { neva.satya@math.untan.ac.id }\end{array} \\ \text { HENDRA PERDANA } & : & \begin{array}{l}\text { Jurusan Matematika FMIPA UNTAN, Pontianak } \\ \text { hendra.perdana@math.untan.ac.id }\end{array}\end{array}$

